\title{
Balanced reading instructions: An action research on elementary cram school students
}

Chou, Chuing Prudence

National Chengchi University, Taiwan, ROC (iaezcpc@nccu.edu.tw)

Wang, Shirly

Dian Harapan School, Indonesia (jliia79@yahoo.com)

Ching, Gregory S.

Lunghwa University of Science and Technology, Taiwan, ROC (gregory ching@yahoo.com)

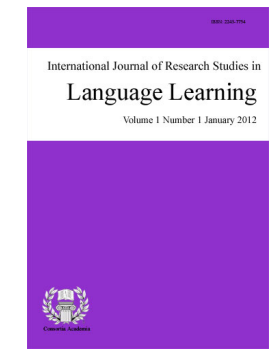

ISSN: 2243-7754 Online ISSN: 2243-7762

OPEN ACCESS

\section{Abstract}

English language learning as the first and foreign language has always been an important factor in a child's life as a student. As the usage of the English language becomes ever more apparent, East Asian nation like Taiwan has started to place much focus on its teaching. However, many parents in Taiwan are still unsatisfied with their children's English abilities at formal school; thus, they send their children to cram school. Most parents' objective is to improve their child's reading ability and attitude, by means of exploring any effective teaching strategies. In light of this, the main objective of this study is to determine how balanced reading instructions will enhance English learning effectiveness among English as Foreign Language learners. An action study was done in order to identify teaching effects of a balanced reading instruction. A pilot study was first accomplished, which later served as the backbone of the formal study. Participants were fifteen (15) first graders in an English cram school in Taipei, Taiwan. Data were gained from abecedarian reading assessment, reading attitude questionnaires, observations, interviews and recordings. Results showed that balanced reading instructions worked better for low to intermediate level students' letter knowledge, phonological awareness, and reading attitude. In addition, balanced reading instruction also help built-up students' confident and created a healthy learning environment by collaborating the stronger readers to help weaker readers in the classroom.

Keywords: balanced reading instructions; letter knowledge; phonological awareness; reading attitude; EFL; cram school 


\section{Balanced reading instructions: An action research on elementary cram school students}

\section{Introduction}

The East Asian island state of Taiwan is internationally recognized for its economic endeavors. According to a 2007 World Bank assessment, Taiwan was quoted to ranks 19th worldwide in terms of knowledge based economic competitiveness (GIO, 2007c, p. 80). Policymakers and scholars examining the Taiwanese economic miracle, questions how and why Taiwan has prosper (Breznitz, 2005). Among these factors, the role and influence of education is widely viewed as a key to the nation's modernization (GIO, 2007b). As the island state engages more centrally as a player in the global economic stage (Mok, 2005; Zaharia \& Gilbert, 2005), the trend of English as an international language becomes an increasingly important element for the education of Taiwan students. In its role as a global language, English has become one of the most important academic and professional tools (Schutz, 2006). Therefore, great importance is emphasized in the finding of an effective way in teaching English to Taiwan's students.

English language education has been a compulsory part of secondary schooling (junior high school) in Taiwan since 1968. Starting 2001, English was introduced at the elementary level of Grade 5, and later on in 2005, the Ministry of Education (MOE) decided that all the elementary school students started to learn English from third grade (GIO, 2007a; Oladejo, 2005). In Anderson, Hiebert, Scott, \& Wilkinson (1985) report on the commission of reading entitled; "Becoming a Nation of Readers", they mentioned: "Reading is a basic life skill. It is a cornerstone for a child's success in schools, and indeed, throughout life. Without the ability to read well, opportunities for personal fulfillment and job success will be lost." However teachers in Taiwan have been confronting several difficulties in teaching English at elementary schools. As a first grade English as a Foreign Language (EFL) teacher (EFLT) for more than four years in Taiwan, the researcher believed that teachers should be resolute in providing the best instruction which would enable students to become fluent and competent readers of English. Therefore as a language researcher and practitioner in this present study attained to reach understanding of factors that are involved in Taiwanese students' English reading development.

In addition to attending English classes, many students particularly in the metropolitan areas, take English courses at cram schools, which are independent after-school learning establishments (Her, 2007). Parents in Taiwan are willing to sacrifice their financial for they believed that by sending kids to an expensive language school; consisting of a local teacher and an English-speaking foreign teacher in each class, will aid their children in the highly competitive globalize world of today (Peng, 2008). Besides, parents possessed a high expectation that their children will possess a higher achievement in English language learning during their time in cram schools. The reasons above motivated the researcher to undergo a study, which would determine a better approach in English language teaching in Taiwan.

\subsection{Research questions}

Reading is a pivotal proficiency for academic success, it is crucial that as to researcher and practitioner alike, should attain a rich understanding of the factors that are involved in Taiwanese students' English reading development. Despite the abundance of previous researches, more studies are needed to further investigate the effects of balanced reading instruction on Taiwanese EFL students. In addition, there is a need to help improve reading ability and more significantly aid the students' learning attitudes towards English. With these in mind, the main purpose of this research is to determine how effective Balanced Reading Instruction program to the EFL beginners in the classroom. The researcher believes that her goal as a purposeful teacher is to provide the best instruction that would enable students to become fluent and competent English readers. 
Balanced reading instructions: An action research on elementary cram school students

1. How will balanced reading instruction program affect EFL beginners' letter knowledge and phonological awareness?

2. How will balanced reading instruction program affect EFL beginners' reading attitude?

\section{Literature review}

\subsection{English as a Global Language}

In its role as a global language, English has become one of the most important academic and professional tools. Gove (1986) mentioned in his preface to Webster's Third New International Dictionary illustrates this point: "It is now fairly clear that before the twentieth century is over every community of the world will have learned how to communicate with all the rest of humanity. In this process of intercommunication the English language has already become the most important language on earth (p. 5a)." While Crystal (1997) adds: "As English becomes the chief means of communication between nations, it is crucial to ensure that it is taught accurately and efficiently (p. 3)."

English as we know is derived from the language of the Angles, Saxons and Jutes. Until the early 1600s only a few million people spoke English. They lived on a small island in the North Sea. The English traveled all over the world and settled. The areas where the English settled were called colonies. Trade between the mother country and the colonies became an important factor. The language used was English. Now English has for more than 150 years been called a world language (Engleza, 2006). English is present on every continent. In over 60 countries it is used officially or without the sanction of government and is prominent in 20 more. There are three kinds of English speakers, those who speak it as their first language, those who speak it as a second language and those who learn it a foreign language. Today about 400 million people speak English as their mother tongue or first language. Over 50 million children study English as an additional language at primary level and over 80 million study it at secondary level.

In Taiwan, English is highly regarded as the global language in the areas of research, technology, trade, commerce, tourism, and banking (S. Tsai, 1998). English is the link language between people from diverse cultures and different countries in this global village (Wang \& Savignon, 2001). In order to express the importance of this global language, Taiwanese government has put heavy emphasis on citizens' English education for the past few decades, thus, making English language teaching and learning a highly valued part of education in Taiwan.

\subsection{Importance of Reading in Taiwan}

Reading is a basic life skill. It is a cornerstone for a child's success in school, and, indeed, throughout life. Without the ability to read well, opportunities for personal fulfillment and job success inevitably will be lost. Reading is a foundational skill in all children's academic careers; whether they become strong or weak readers has considerable bearing on their success in school and beyond (Snow, Burns, \& Griffin, 1998). Reading is also a process of mentally interpreting written symbols. It involves a series of factors that a reader brings to the text (Li, 1992). These skills include a reading ability to monitor their own comprehension decode unknown words and fix-up strategies.

Reading ability includes understanding ability and reading speed. Understanding needs to consist of understanding both the surface structure and the deep meaning that author express with words and then understand it's inside meaning. Whether reading ability is good or not depends on reading speed as well as understanding level. Reading speed and reading comprehension are two elements that cannot be separated. Poor reading ability surely results in slowdown reading speed. Neglect of reading speed must have a bad effect on reading comprehension ( $\mathrm{Wu}, 2003)$. 
Many mentioned that reading is of great importance in basic linguistic knowledge acquisition and English language learning. Reading is very vital to English learning. In reality, reading doesn't demand too much perquisites, a person is capable of reading a great deal of materials available everywhere, such as magazines, books, newspapers and so on. More importantly, a person can read anywhere and anytime. In Taiwan, the Ministry of Education (MOE) has highlighted the importance of English learning and reading. According to the general guidelines of grades 1-9 elementary curriculum (MOE, 1997), English language learning programs for Grade 5 and Grade 6 were implemented in the school year 2001. Then on, after four years, English language learning programs were implemented for Grade 3 in the school year 2005.

An important foundation of the English reading process is early preparation. In the revised curriculum goals, an important article was added, which is to recognize the twenty-six letters of the English alphabet in listening; to be able to speak the twenty-six letters in speaking; to be able to recognize the twenty-six letters in reading; and to be able to write the twenty-six letters in writing (MOE, 2001). These goals are the very core and essential steps in helping Taiwanese students cultivate a better English learning environment. Influenced by the US program of No Child Left Behind (NCLB), in 1996, Taiwan started to implement its goals in the Action Plan for Educational Reform; which is to teach each student well (Fan, 2006). A lot of efforts are now being placed on low achievers or underachievers. In order to solve the problem, many studies have proved that early intervention and remedial instruction can help in nurturing the students' learning ability (Pikulski, 1994; Torgesen, 2000). Furthermore, some researchers mentioned that from the positions of the government, it is helpful to have remedial instructions during the early stages, for this will lower future social cost (Berk, 1996; Shanahan \& Barr, 1995). Thus, it is important for remedial schools such as cram schools, in helping the students learning abilities.

\subsubsection{Letter knowledge}

Alphabet knowledge is also known as Letter Knowledge; which is a crucial aspect of early readers. To be a successful reader, besides being confidence, students will need to become familiar with the letters of the alphabets. They should know them by heart; without any hesitation and confusion. Students who have the ability to identify letters of the alphabets (by whatever means, letter name, sound or a word that begin with letter) is one of the best predictors of a future successful reader (Strickland \& Schickedanz, 2004). Blaiklock (2004) also mentioned that in some previous researches, results have showed positive association about controlling letter knowledge in the students early reading years, however, it reduced most correlations to no significant levels.

Alphabet knowledge includes the knowledge of letter names and the knowledge of letter sounds. Letter-name knowledge measured in kindergarten is the one of the best predictors of future reading and spelling achievement (Badian, 1995; Ehri \& Sweet, 1991). Children who can identify some letters are capable of demonstrating that they are noticing print, developing their visual memory, and distinguishing among letters forms. According to Burns, Griffin, and Snow (1999) by the end of kindergarten, children should be able to name most of the letter alphabet, no matter what order they come in, no matter if they are uppercase or lowercase. And they should do it quickly and effortlessly. Hence, this stage is considered a crucial part of the child's development. At the level of preschool, children are generally expected to know at least ten (10) uppercase letters. Know how to spell their names and parents and teachers suppose to provide more opportunities for children to learn letter names as part of a variety of rich and oral language experiences (Strickland \& Schickedanz, 2004).

\subsubsection{Phonological awareness}

Phonological awareness is the understanding of words which are made up of speech sounds, or phonemes. The words are made up of syllables, onsets rimes, and many others. Children however are very concrete thinkers, and they tend to be unaware of these abstract characteristics of spoken words, therefore many children will have similar problem in representing words (Wren \& Watts, 2002, 2003a). Phonemic Awareness is part of phonological awareness which showed the ability to hear, identify, and manipulate the individual sounds (phonemes) in spoken words and it links directly to phonics, which relates sounds to letters that represent them. 
Balanced reading instructions: An action research on elementary cram school students

Indeed, instruction in phonemic awareness may involve the use of print (Strickland \& Schickedanz, 2004).

Letter knowledge is actually necessary or a pre-cursor for the development of phonological awareness. They supported learning to spell may facilitate a child's understanding of grapheme phoneme relationship in alphabetic language to some extent. Researchers have shown that the relative stability of phonological awareness and the importance of this awareness as a precursor to the development of word identification and spelling skills.

\subsubsection{Reading attitudes}

Through learning, students can not only develop various capabilities but establish the internal states that influence their choices of personal actions. These outcomes of learning are called attitudes (Gagne, 1985). Because of the influences of attitudes on learners' behavior, teachers should focus on students' affective change in addition to students' cognitive performance.

Reading attitude is related with readers' perceptions and points of views, such as likes or dislikes the reading materials during the processes of reading. According to Alexander and Hearhington (1988) affective domain related to reading comprises four elements: attitude toward reading, motivation for reading, reading interest, self concept to related reading. They also state that reading attitude is the most important element among these four elements. Similarly, Fishbein and Ajzen (1975) emphasized that reading attitude is a definition of student's reading belief, reading feeling, and reading behavior.

\subsubsection{Letter knowledge, phonological awareness and reading attitude}

Why it is said that alphabet letter knowledge such a powerful predictor of future reading success? Because letter knowledge is one of the aspects in the early literacy-rich environment by providing children with books and print experiences. Besides letter knowledge helps children to connect printed words with spoken language which then will facilitate their letter-sound knowledge. Letter-sound knowledge requires a higher level of phonological awareness skills than does letter naming. Phonological awareness contented rhyming perception, phoneme identity-perception, rhyming production and phoneme identity-production which support the children to build correlations between letters and sounds (Wren \& Watts, 2002).

The above mentioned two skills show differential predictive effects that should be a better predictor of reading fluency because it reflects a greater depth of grapheme-phoneme knowledge and automaticity (Strickland \& Schickedanz, 2004). Some researchers from Florida State University; Hecht, Burgess, Torgesen, Wagner, and Rashotte (2004) made a research of beginning kindergarten from their first to fourth grade years in reading ability. It shown that reading abilities were related to phonological awareness, rate of access to phonological information in long-term memory, and print knowledge. When they have sufficient knowledge of letter knowledge and phonological awareness skills they won't be hesitate and confuse in reading the print during their reading time.

\subsection{Balanced Reading Instructions}

\subsubsection{Definition}

Balanced reading instruction usually means a combination of whole language and phonics approaches. Researchers and practitioners alike assert that children need training in both phonemic awareness, by which they develop awareness of individual sounds--and in cueing strategies--through which they learn to decode the text and comprehend the material (Kelly, 1997). While, Honing (1996) defines balanced reading instruction as one that combines language and literature rich activities associated with whole language, through explicit teaching of the skills needed to decode words. Balanced reading instruction brought out the spirit of whole language and the skill for teaching phonics (Michael Pressley, 2006).

Cowen (2004) stated that a balanced reading program should provides the authentic, comprehensive, 
integrated and supportive opportunities in children's literacy development. Cowen's descriptive explanation about balanced reading program is indicative of some professional group of elementary teachers who are open to change and incorporate a comprehensive and integrated approach to literacy for the benefit of all children.

Based on more than 20 years of experience as a classroom teacher and more than 30 more years of researching balanced approaches to reading instruction, Cowen (2004) mentioned that "A balanced reading approach is research-based, assessment-based, comprehensive, integrated, and dynamic, in that it empowers teachers and specialists to respond to the individual assessed literacy needs of children as they relate to their appropriate instructional and developmental levels of decoding, vocabulary, reading comprehension, motivation, and socio-cultural acquisition, with the purpose of learning to read for meaning, understanding and joy." In essence, the balanced reading approach has been celebrated for offering an alternative to the extremes of pure phonics or whole language; for providing an effective combination of instructional approaches; and for accommodating various learning styles (M Pressley, Weaver, \& Alterman, 1998; Weaver, 1998).

\subsubsection{Principles of balanced reading instructions}

A balanced approach requires and enables a teacher to reflect on what he or she is doing and to modify instruction daily based on the needs of each individual learner. So there are some points which become balanced approach considerations according to (Blair-Larsen \& Williams, 1999) which learners, teachers, curricular, and schools varies and children deserve consistent curriculum. Holdaway (1979) presents four strategies of a balanced program that have existed in New Zealand for more than two decades:

$>$ Guided reading - involves a teacher working with a small group of four to six children reading individual copies of the same text. The texts are selected by the teacher to be at the children's learning level. The texts have some challenges and the teacher prepares the children to use a range of problem solving strategies to read them. The texts used over successive sessions should have a careful gradient of difficulty (Hill, 1999).

$>$ Independent reading - the purpose is to build fluency and motivation for reading. Children are encouraged to read texts at their independent reading level so that reading is practiced and fluency is increased. Each child is challenged to read on their own for a sustained period of time (Hill, 1999).

$>\quad$ Shared reading - is usually a whole group activity and although it is led by the teacher, children can participate in the reading in various ways, including choral reading and readers' theatre. The focus for shared reading may be to learn how to read various text types, how to solve problems in identifying various words or, at the sentence level, the way punctuation and grammar are used to communicate meaning (Hill, 1999).

$>\quad$ Language experience approach - supports children's concept development and vocabulary growth while offering many opportunities for meaningful reading and writing activities. Another benefit of the language experience approach is the development of shared experiences that extend children's knowledge of the world around them while building a sense of classroom community. Students are involved in planning, experiencing, responding to, and recording the experience and later, in participating in remember when we? type of conversations (Regina, 1992).

2.3.3 Related studies on balanced reading instructions

In order to gain better insights on previous research done on balanced reading instructions, a thorough compilation of foreign studies related to balanced reading instructions were compiled. Listed below are some of the research descriptions, which were found to be of support to the current research:

Baumann (1996) in the study entitled "Reports on a nationwide survey of instructional beliefs and practices of elementary public school teachers", finds that teachers generally do not assume a polar, either/or approach to 
phonics and whole language, but instead provide children a balanced eclectic program involving both reading skill instruction and immersion in enriched literacy experiences. While, Pressley, Weaver, Kelly \& Alterman (1998) in their study entitled "A study of effective first-grade literacy instruction", mentioned that most of elementary teachers use whole language and phonics skills in balanced reading instruction among their classes which improves the students reading ability and involves multiple instructional components articulated with one another.

In a book edition by Baltas \& Shafer (1996) entitled "Scholastic guide to balanced reading $k$-2: Making it work for you", they mentioned that balanced reading instruction programs gives educators a chance to step into actual classrooms where teachers have successfully implemented effective programs. While Foorman (1996), in her study entitled "An experiment comparing balanced grade-1 to whole language and skills emphasis instruction", stated that the students in balanced instruction were doing much better than students either in the whole language or skill emphasis classrooms. Furthermore, Abbott, Reed, Abbott \& Berninger (1997), led sixteen (16) children with severe reading problems in the first grade, to receive a year-long individual tutorial intervention. Results showed that the children improved a lot on the measures of orthographic and phonological coding, word identification, word attack skills, reading comprehension, letter automaticity, and spelling.

In the research of Gunner, Smith \& Sauda (1999), a balanced reading program was implemented to improve students' attitudes toward reading and to promote comprehension within the target classrooms. Result showed that there was an increased growth in reading comprehension within all targeted grades. A post survey showed that students' attitude improved. In addition, Pernai, Pulciani \& Vahle (2000) tested the effectiveness of the implementation of the Hello reader scholastic phonics program as an addition to an already rich, literature based curriculum. Results showed that a balanced reading program successfully enhanced student's growth in upper case letter identification, lower case letter identification, letter/sound recognition, and pre-primer word identification.

Actually, a balanced reading instruction is not really popular in Taiwan yet, but perhaps some elementary teachers have implemented this instruction without deeply understanding of it. The below are some summaries of balanced reading instructions researches in the Taiwan contexts, mostly in elementary school. In a paper entitled "The effects of balanced reading instruction on elementary school students" English word recognition, reading comprehension and reading attitude, the researcher mentioned that balanced reading instructions was beneficial in enhancing students' English word recognition, improve students' English reading comprehension ability, did not enhance students' attitudes toward reading English children's books (Fu, 2008). In addition, Tsai (2006) dissertation entitled "Balanced reading instruction model and the experimental study on the effects of this model for EFL Students in senior high school", mentioned that balanced reading instructions was able to enhance students' word-reading ability, helped enhance students' English reading comprehension ability, could improve the students' attitude toward English reading.

In summary, from the previous discussed researches from both foreign and local sources, some general facts can be noted. First, most elementary school teachers support a balanced reading instruction. Second, a balanced reading instruction is helpful to developing students reading ability and interest. Third, a balanced reading instruction can work in both first language learner and second language learner classrooms.

\section{Research methodology}

Action research has been used in many areas, where an understanding of complex social situations has been sought in order to improve the quality of life. Kurt Lewin; often cited as the originator of action research, used the methodology in his work with people affected by post-war social problems (McKernan, 1991). Action research approaches to educational research were adopted in the late $60 \mathrm{~s}$ and early 70 s by the teacher-researcher movement in the secondary education sector. Its combination of action and research had contributed to the attraction to researchers, teachers, and the academic community alike (Cohen, Manion, \& Morrison, 2007). 
Action research into our own teaching practice is an important source of learning for the teachers. Here, we can describe the nature of action research, and describe its use in the on-going development and evaluation of a new teaching modules. It is the goal of an action research to approach teaching, and to improve the teaching and learning practices. This also sought to bring the practicing classroom teacher into the research process as the most effective person to identify problems and to find solutions. The scope of action research as a method is impressive. It can be used in almost any setting where a problem involving people, tasks and procedures cries out for solution (Cohen et al., 2007).

All of the above mentioned researches adopt a methodical, iterative approach embracing problem identification, action planning, implementation, evaluation, and reflection. The insights gained from the initial cycle feed into planning of the second cycle, for which the action plan is modified and the research process repeated. Kolb (1984) extended this model to offer a conception of the action research cycle as a learning process, whereby people learn and create knowledge by critically reflecting upon their own actions and experiences, forming abstract concepts, and testing the implications of these concepts in new situations. Practitioners can create their own knowledge and understanding of a situation and act upon it, thereby improving practice and advancing knowledge in the field.

\subsection{Case selections}

In the beginning of the semester in February 2008, First graders of various backgrounds were facing difficulties in reading. Most of them felt that English language learning was too hard for them. Students have poor word recognition, reading comprehension and may be unfamiliar with the perception between letters and their sounds. Some of them have no confidence because they have a lack of understanding of the instruction, or they have poor listening ability. Consequently, it is boring for them to attend class, which may result in a loss of interest in learning English in the future. As a teacher and practitioner in the First grade class, the researcher tried various techniques and strategies, and tried to find out which was the most effective instruction. From then on, every statement that the researcher encountered during her academic studies were used and developed towards answering the question on how to find more effective ways and strategies in teaching English language to the students.

Fifteen (15) participants were divided into three (3) levels of reading proficiency. Twelve (12); ages 6 to 8 , of the participants came from the same elementary school, and two (age 5) came from the same kindergarten. While, the remaining student (age 5) came from another kindergarten. The participants were ten boys and five girls. They were coded as SB1, SB2, SG3, SB4, SB5, SB6, SG7, SB8, SG9, SG10, SB11, SB12, SB13, SG14, and SB15 (NOTE: SB is Student Boy, while SG is Student Girl). Table 1, shows the background of the student participants.

Participants are mostly kindergarten students, first grade students, and second grade students in the elementary school. Their English proficiencies were categorized at low or basic level. SB1, SB2, SG3, and SB4 have prior basic knowledge of English as they can spell and read some short vocabulary words. The researcher categorized these four participants as better level reader in the first grade class. SB6 and SB11 have family supported English knowledge so they also knew basic English letters and alphabets sounds, even though they possess little skills in listening and speaking, they still need to improve their reading and writing skills, while, the rest of the participants were classified as beginners. In addition, the elementary school were the participants are enrolled, are considered to be of good quality.

\subsection{Data collection methodology}

In order to gather information and produce evidence to show the effectiveness of balanced reading instruction affected their letter knowledge, phonological awareness and reading attitude in English, data was collected from several sources to allow triangulation. The quantitative data included the Abecedarian reading 
Balanced reading instructions: An action research on elementary cram school students

assessment test (Wren \& Watts, 2002, 2003a), running records of reading behavior from individual reading, work samples from student reading response journals. The qualitative data included excerpts from teacher's journal, anecdotal of reading activities, and the voices of students, parents and colleagues, as expressed in recordings, conversations, observations, pre and post-test of reading attitude questionnaire, surveys and interviews.

\section{Table 1}

Description of students' background

\begin{tabular}{|c|c|c|c|c|c|c|}
\hline Student & Sex & Age & $\begin{array}{l}\text { English learning } \\
\text { background }\end{array}$ & $\begin{array}{l}\text { Cram school } \\
\text { experience }\end{array}$ & $\begin{array}{l}\text { Parent's } \\
\text { education } \\
\text { background }\end{array}$ & $\begin{array}{l}\text { English } \\
\text { learning } \\
\text { supported } \\
\end{array}$ \\
\hline SB1 & $\mathrm{M}$ & 7 & Kindergarten & 3 years & Bachelor & Non \\
\hline SB2 & M & 6 & Kindergarten & 3 years & Master & Medium \\
\hline SG3 & $\mathrm{F}$ & 6 & Kindergarten & $31 / 2$ years & Businessman & \\
\hline SB4 & $\mathrm{M}$ & 7 & Kindergarten & $31 / 2$ years & Businessman & \\
\hline SB5 & M & 6 & Kindergarten & 6 months & Bachelor & \\
\hline SB6 & $\mathrm{M}$ & 5 & None & None & Bachelor & Non \\
\hline SG7 & $\mathrm{F}$ & 6 & None & None & Bachelor & Non \\
\hline SB8 & $\mathrm{M}$ & 5 & None & none & Business & Non \\
\hline SG9 & $\mathrm{F}$ & 6 & None & None & Bachelor & Non \\
\hline SG10 & $\mathrm{F}$ & 7 & None & None & Businessman & \\
\hline SB11 & $\mathrm{M}$ & 6 & Kindergarten & 3years & Bachelor & \\
\hline SB12 & $\mathrm{M}$ & 6 & None & None & Bachelor & \\
\hline SG13 & $\mathrm{F}$ & 5 & None & None & Businessman & \\
\hline SB14 & $\mathrm{M}$ & 6 & None & None & Bachelor & \\
\hline SB15 & M & 6 & None & None & Businessman & \\
\hline
\end{tabular}

\subsubsection{Observation}

Field observations of sixteen (16) weeks classroom activities carried out one time a week over months of the first school term in the 2008 academic year. The observations conducted during the balanced reading instruction sessions at the English classroom were in the form of participant-observation, in which the researcher was available for providing any assistance if needed. The observations focused on weaker reader' letter knowledge, phonological awareness, and also their reading attitude or responses to the texts. How they interact with the physical environment, the books, the rewarding, and their reading partners are also part in the observations. These sessions were partly video-taped; the research site atmosphere and incidents were jotted down in the researcher's field notes. Afterward the contents of the field notes were transcribed word by word and analyzed.

\subsubsection{Interviews}

Interviews were conducted to understand the experience of the participants and the meanings they make of their experiences. Interviews are particularly important when one is interested in gaining participants' perspectives, the language and meanings constructed by individuals. Five students were selected to be interviewed during this study. The selection was based on the participants' performances during the present study. The colleagues were also selected as the interviewees to encounter problems among other students. 


\subsubsection{Abecedarian reading assessment}

Effective reading instruction begins with assessment (Pearson, 2006). Individual children come to class with such diverse literacy backgrounds, it is not safe to assume that they will all learn to read the same way and that they will all benefit equally from classroom lessons. Reading is a skill, and as such, teachers should begin by determining what skills and knowledge each child already has, and the teacher should customize instruction to the individual learning needs of the students (Anderson et al., 1985). Good reading instruction also begins with assessment (Pearson, 2006). The need for assessment stems from the fact that children are not all identical. If all children were identical, instruction would be a whole lot easier (Wren \& Watts, 2003b). Wren and Watts (2003a) also mentioned that an effective teachers teach children what they are ready to learn, and do not waste time teaching children what they already know. Reading assessments help teachers keep track of the zone of proximal development for each child, so instruction can be designed which is neither too easy nor too challenging.

Children arrive in class with a maddening diversity of understandings and experiences, especially when it comes to reading. The teacher cannot make any assumption about what the child knows and what the child still needs to learn when it comes to developing literacy skills. To be successful and efficient, teachers must be adept at making a quick assessment of each child's reading and pre-reading skills, and further, teachers must be adept at using that assessment information to make decisions about what instruction each child should receive (Wren \& Watts, 2003b). Assessment can be a straightforward observation of a child's behavior when writing; it can be an observation of how well a child plays a word game; it can be an observation of a child's oral reading fluency. Every observation has the capability to be an assessment. It is a good idea, however, to bring together teacher observations with more formal and objective assessment information - the two complement each other, and give the teacher a much better informed picture of each child's reading-related skills.

The Abecedarian was designed to prove diagnostic information about early reading skills. It is divided into six major subtests. Most of these subtests are further broken into a variety of tasks. The subtests are further broken into a variety of tasks. The subtests and the tasks were selected and created with the best research information available. The preponderance of research evidence suggests that children who have phoneme awareness in kindergarten are much more likely to be successful readers in third grade than children who lack phoneme awareness (Wren \& Watts, 2003a).

Research has visibly shown the benefits of developing all of the knowledge domains tested by the Abecedarian early. The preponderance of research indication suggests that children who have phoneme awareness in kindergarten are much more likely to be successful readers in third grade than children who lack phoneme awareness. Similarly, knowing the letters of the alphabet is one of the best predictors of reading success. The same is true of knowledge of the alphabetic principle and word recognition skills. Vocabulary knowledge both predicts and is a result of reading success, as is decoding fluency (Wren \& Watts, 2003a).

It is recommended that all students be able to pass the Letter Knowledge, Phoneme Awareness, and the Alphabetic Principle subtests by the beginning of the first grade. And by the end of the first grade, students should be able to pass the rest of the subtests. The ground rules of assessment are not necessary to give every part of the Abecedarian to every student so teacher should know the strategic. For example, if a student passes the Decoding - Fluency section, it is sure that the students are not necessary to take Letter Knowledge or Alphabetic Principle Assessments. The assessment increase in difficulty and the teacher should put in into consideration. The philosophy that underlies the Abecedarian is that assessment is important to inform instruction, but excessive assessment is a waste of time. Teacher should not miss the opportunity to know their students literacy skills better (Wren \& Watts, 2002, 2003a).

\subsubsection{Researchers' journal}

In this study, qualitative research was the major method of the project; therefore reflexive journals (field notes, interview notes, observation notes) were kept as the study moved on. The journal is a source of valuable 
Balanced reading instructions: An action research on elementary cram school students

reflection for the researcher. The researcher's journal in this study served several purposes: first, it evidenced the crucial reflection about the researcher's biases throughout the study. Second, it proposed an opportunity to reflect on what was occurring in the study and to keep a record of decisions and issues that were particularly important in tracing the evolution of a continual study. Third, the journal extended an account of the researcher's evolution in terms of methodology, methods choices, and development as a researcher.

\subsubsection{Running records}

The running record represents the book that one of the students read. Running record can tell us a great deal more than just the match between child and text, however. They are invaluable tool for helping teachers observe exactly which types of miscues children are making, and how children are attempting to make use of the interactive cue systems (for example, graphic, syntactic, semantic, visual) in word identification (Clay, 1994). It helped teacher analyze student's specific reading behaviors such as monitor their own miscues, self corrected and cross-checked. Running record revealed the students' independent as a reader.

\subsection{Data analysis procedures}

When data were collected and throughout coding then analyze the data. The data in the present study were organized and analyzed by using the constant comparative method (Glaser, 1978). Therefore analysis process consisted of three (3) steps. At the first step involved the researcher's reading and re-reading the data to discover units of meaning and assigning a code to each unit.

The second step was to categorize all the units of meaning. The researcher has to sort and placed some units of meaning into temporary categories based on the look/feel-alike criteria. Then a summary was written for each category, and each unit was reselecting to determine whether it compound category rule or if it should be categorized in elsewhere. If a unit of meaning could not be classified under any category, a new category was formed. Affiliate if certain categories contained insufficient data, the researcher returned to the field to collect more data. After all the units of meaning were categorized and coded, the researcher reviewed those categories for any overlap and ambiguity and refined the categories if necessary. In the process of categorizing data, the researcher also had to fixed with negative and discrepant aspects; rules for conclusion and categorization were revised to account for all the cases.

During the process of study and investigating, some categories were intervened, some deleted, some were mixed or joined with a more general category, and some new ones were added. The data collection and data analysis continued until the theoretical saturation point was reached (Strauss \& Corbin, 1990); that was when all the categories and relationships between categories were well supported. At the end, the researcher tried to integrate all the data and observed the relationships and major point among categories. These points formed the results of the study. The research report was then written up to present the results.

The study lasted for more than five months, during this time of instruction the researcher kept open conversations, reflections, and shared critically thinking with other colleagues. Classes are also observed by the English director, which were then on developed into the curriculum and intervention. At the end of the five months, the researcher then gathered the data and generalization were made.

\section{Results and discussions}

As research shown that children learning to read should be able to easily and automatically discriminate the letters from each other (Wren \& Watts, 2003a). The ability to quickly identify letters of the alphabet (by whatever means, be it letter name, sound, or a word that begins with the letter) is one of the best predictors of future reading success. The original test has six subtests, by the beginning of the first grade three subtests were implemented; Letter Knowledge, Phonological Awareness, and Alphabetic Principle. Teachers should be strategic and know which part of the assessments should be added to determine the students' ability in English 
early reading. Letter knowledge subtest motivated and enforces students to be quickly and correctly identify upper-case and lower-case letters (mixed) of the alphabet. Students must also not incorrectly identify "foil" as letters (e.g. numbers, punctuation marks, etc.). Phonological Awareness included rhyming and identifies perception also rhyming and identifies production. Identify first and last sound also segmentation. The subtest of Alphabetic Principle was to determine which of two written words were being spoken by the teacher (length of word).

\subsection{How will balanced reading instruction program affect EFL beginners' letter knowledge and phonological} awareness?

\subsubsection{Knowledge awareness}

Letter knowledge is the ability to quickly identify letters of alphabet (by whatever means, be it letters name, sounds, or a word that begins with the letter). The researchers mentioned that the familiarity of letters of alphabet has consistently shown to be a strong predictor for future reading success at the same time important for developing decoding skills. Typically, testing a child's knowledge of letters of alphabet usually contains upper-case letters, lower-case letters, and a few odd characters, or might be numbers or punctuation marks as well to increase challenge.

A total of sixty (60) items were tested, including the twenty-six (26) uppercase letters, twenty-seven (27) lowercase letters, and five (5) numbers and two (2) punctuation marks added. The assessment results revealed that before the program (please see Table 2), SB1 performed correctly on 56 items of the letter knowledge; SB2 57, SG3 56, SB4 58, SB5 51, SB6 58, SG7 47, SB8 38, SG9 49, SG10 50, SB11 47, SB12 40, SG13 37, SB 14 36 , SB15 29. They were all improved after the program and as seen in the table 2 the six (6) of the participants SB1, SB2, SG3, SB4, SB5, and SB6 showed slight progress. This might have related to their prior knowledge which had ever learned English before they came to the present cram school.

They were then categorized as strong readers that helped the weaker readers in reading partners program. The other participants SG7, SG9, SG10, and SB11 were categorized as middle level readers. The problems appeared from the participants during test were because of confusion and hesitation when they see the punctuation marks and also the fonts of letter "g" and " $g$ ". They were distracted by the odd characters and that caused them not comfortable to answer correctly. Furthermore, five (5) of the participants SB8, SB12, SG13, SB14, and SB15 have shown lacked letter knowledge of alphabet. They were all beginners and really need intensive attention in learning English. During the test was taken, they showed a very strong hesitations and confusions to read out those letters. Teacher had to read the letters that they didn't feel comfortable with them repeatedly.

It is important that children become familiar with letters knowledge in text because it is represent the phonemes in speech - that is the alphabetic principle which is the cornerstone on which all reading skill is built. During the program SB2 performed excellence attitude for being reading partner and helper, his personality helped other weaker readers to acquire the letter knowledge impact other participant's willingness to help other weaker readers which reinforced the concept of letter-sound correspondence. Their improvement might have partly resulted from reading phonics and spelling books used in the program. These books provided practice of letter sounds and common rimes. These texts provided chances for repeated encountering of the same letter sound. In addition, the way that the reading partner read with the weaker readers using phoneme segmentation helped them capture the sounds. 
Balanced reading instructions: An action research on elementary cram school students

Table 2

Results of letter knowledge pre/post test

\begin{tabular}{|c|c|c|c|c|}
\hline \multicolumn{3}{|c|}{ Before program } & \multicolumn{2}{|l|}{ After program } \\
\hline \multirow{2}{*}{ SB1 } & Uppercase 25, Lowercase 26, Signs 5 & 56 & Uppercase 25, Lowercase 28, Signs 6 & 59 \\
\hline & $\mathrm{g}, \mathrm{q}, \mathrm{!}, ?$ & 4 & $!$ & 1 \\
\hline \multirow{2}{*}{ SB2 } & Uppercase 25, Lowercase 27, Signs 5 & 57 & Uppercase 25, Lowercase 28, Signs 7 & 60 \\
\hline & $\mathrm{g}, !, ?$ & 3 & - & - \\
\hline \multirow{2}{*}{ SG3 } & Uppercase 24, Lowercase 26, Signs 6 & 56 & Uppercase 25, Lowercase 28, Signs 7 & 60 \\
\hline & $X, 1, q, !$ & 4 & - & - \\
\hline \multirow{2}{*}{ SB4 } & Uppercase 25, Lowercase 27, Signs 6 & 58 & Uppercase 25, Lowercase 28, Signs 7 & 60 \\
\hline & $\mathrm{Q}, !$ & 2 & - & - \\
\hline \multirow{2}{*}{ SB5 } & Uppercase 22, Lowercase 25, Signs 5 & 51 & Uppercase 25, Lowercase 28, Signs 7 & 60 \\
\hline & $\mathrm{X}, \mathrm{Z}, \mathrm{U}, \mathrm{r}, \mathrm{k}, \mathrm{q}, ! ?$ & 9 & & - \\
\hline \multirow{2}{*}{ SB6 } & Uppercase 25, Lowercase 28, Signs 5 & 58 & Uppercase 25, Lowercase 28, Signs 6 & 59 \\
\hline & $!, ?$ & 2 & $!$ & 1 \\
\hline \multirow{2}{*}{ SG7 } & Uppercase 18, Lowercase 24, Signs 5 & 47 & Uppercase 25, Lowercase 27, Signs 6 & 58 \\
\hline & M,J,F,Z,S,K,I,q,g,k,m,!? & 13 & $!, ?$ & 2 \\
\hline \multirow{2}{*}{ SB8 } & Uppercase 16, Lowercase 18, Signs 4 & 38 & Uppercase 20, Lowercase 20, Signs 6 & 46 \\
\hline & M,Z,P,Q,W,T,E,K,F,I,l,x,s,r,t,k,g,j,h,!,?,4 & 22 & $\mathrm{~T}, \mathrm{E}, \mathrm{K}, \mathrm{Z}, \mathrm{W}, \mathrm{l}, \mathrm{m}, \mathrm{w}, \mathrm{g}, \mathrm{i}, \mathrm{t}, \mathrm{c}, \mathrm{k}, !$ & 14 \\
\hline \multirow{2}{*}{ SG9 } & Uppercase 20, Lowercase 24, Signs 5 & 49 & Uppercase 25, Lowercase 26, Signs 6 & 57 \\
\hline & $\mathrm{U}, \mathrm{E}, \mathrm{W}, \mathrm{Q}, \mathrm{J}, \mathrm{j}, \mathrm{q}, \mathrm{l}, \mathrm{v}, ! ?$ & 11 & $\mathrm{v}, \mathrm{g}, !$ & 3 \\
\hline \multirow{2}{*}{ SG10 } & Uppercase 24, Lowercase 26, Signs 6 & 56 & Uppercase 25, Lowercase 27, Signs 6 & 58 \\
\hline & $\mathrm{X}, \mathrm{l}, \mathrm{q}, \mathrm{!}$ & 4 & $! ?$ & 2 \\
\hline \multirow{2}{*}{ SB11 } & Uppercase 18, Lowercase 24, Signs 5 & 47 & Uppercase 25, Lowercase 28, Signs 6 & 59 \\
\hline & M,J,F,Z,S,K,I,q,g,k,m,!? & 13 & $!$ & 1 \\
\hline \multirow{2}{*}{ SB12 } & Uppercase 15, Lowercase 20, Signs 5 & 40 & Uppercase 18, Lowercase 24, Signs 5 & 47 \\
\hline & $\mathrm{G}, \mathrm{X}, \mathrm{S}, \mathrm{H}, \mathrm{W}, \mathrm{q}, \mathrm{g}, \mathrm{y}, \mathrm{v}, \mathrm{w}, \mathrm{h}, \mathrm{e}, \mathrm{k}, \mathrm{c}, \mathrm{m}, ! ?$ & 20 & ,J,F,Z,S,M,K,I,q,g,k,m,!? & 13 \\
\hline \multirow{2}{*}{ SG13 } & Uppercase 14, Lowercase 18, Signs 5 & 37 & Uppercase 20, Lowercase 20, Signs 6 & 46 \\
\hline & U,N,Z,P,Q,W,T,E,K,F,I,l,x,s,r,t,k,g,j,h,!,? & 23 & $\mathrm{~T}, \mathrm{E}, \mathrm{K}, \mathrm{Z}, \mathrm{W}, \mathrm{l}, \mathrm{m}, \mathrm{w}, \mathrm{g}, \mathrm{i}, \mathrm{t}, \mathrm{c}, \mathrm{k}, !$ & 14 \\
\hline \multirow{2}{*}{ SB14 } & Uppercase 14, Lowercase 17, Signs 5 & 36 & Uppercase 16, Lowercase 18, Signs 4 & 38 \\
\hline & S,H,W,U,I,q,g,y,v,w, h,e,k,c,m,z,t,!,? & 24 & M,Z,P,Q,W,T,E,K,F,I,l,x,s,r,t,k,g,j,h,!,?,4 & 22 \\
\hline \multirow{2}{*}{ SB15 } & Uppercase 10, Lowercase 15, Signs 4 & 29 & Uppercase 20, Lowercase 25, Signs 6 & 51 \\
\hline & $\mathrm{P}, \mathrm{Q}, \mathrm{Z}, \mathrm{G}, \mathrm{X}, \mathrm{S}, \mathrm{H}, \mathrm{W}, \mathrm{U}, \mathrm{I}, \mathrm{x}, \mathrm{q}, \mathrm{g}, \mathrm{y}, \mathrm{v}, \mathrm{w}, \mathrm{h}, \mathrm{e}, \mathrm{k}, \mathrm{c}, \mathrm{m}, \mathrm{z}, \mathrm{t}, \mathrm{!}, ?$ & 31 & $\mathrm{P}, \mathrm{Q}, \mathrm{Z}, \mathrm{G}, \mathrm{X}, \mathrm{v}, \mathrm{Z}, \mathrm{t}, \mathrm{!}$ & 9 \\
\hline
\end{tabular}

Note. The letters names and the letter sounds in the shaded areas were the ones unknown to the participants. The number in the box represents the number of letter names or letter sounds that the students provided correctly or incorrectly.

\subsubsection{Phonological awareness}

Phonological awareness subtest is made up four tasks: Rhyme Production, Rhyme Perception, Phoneme Identity Production and Phoneme Identity Perception. Many young children have trouble separating the word from what the word represents (such as, ask a child what the longest word he or she know is, and the child may say something like "jump" or "plane"). Thus, the children learn to rhyme words and pay more attention to the first and last sound in words; it will be ultimately lay the basic foundation for developing letter-sound knowledge. (Please see table 3 for the results) Their improvement might have partly resulted from reading phonics and spelling books used in the program. These books provided practice of letter sounds and common rimes. These texts provided chances for repeated encountering of the same letter sound. In addition, the way that the reading partner read with the weaker readers using phoneme segmentation helped them capture the sounds.

In addition, paired sample T-test was also accomplished with results as follows. The paired-samples T-test was conducted to evaluate the impact of the BRI lessons on the students' Letter Knowledge scores. Results show that there is a significant increase in the students' Letter Knowledge scores from Pre-test $(\mathrm{M}=47.67, \mathrm{SD}=9.65)$ to Post-test $(\mathrm{M}=54.53, \mathrm{SD}=7.06), \mathrm{t}(29)=-4.811, \mathrm{p}>0.000$. The table 4 also showed the impact of the BRI program on the students' Rhyming Perception scores. Results show that there is a significant increase in the students' Rhyming Perception scores from Pre-test $(\mathrm{M}=8.43, \mathrm{SD}=5.21)$ to Post-test $(\mathrm{M}=16.29, \mathrm{SD}=2.37)$, $\mathrm{t}(27)=-9.033, \mathrm{p}>0.000$. As it shown on the table that students' Phoneme Identity - Perception and Rhyming Production also increased from Pre-test $(M=8.64 \mathrm{SD}=3.65)$, Post-test $(\mathrm{M}=17.00 \mathrm{SD}=1.92), \mathrm{t}(27)=-15.173$, $\mathrm{p}>0.000$ and Pre-test $(\mathrm{M}=8.14 \mathrm{SD}=4.57)$, Post-test $(\mathrm{M}=16.07 \mathrm{SD}=2.06), \mathrm{t}(27)=-9.348, \mathrm{p}>0.001$. Every sub-task has interrelation with each other except the Phoneme Identity - Production. They mostly 
Chou, C. P., Wang, S., \& Ching, G. S.

correlated to each other in the similar level, which also mean that the students made changes by the average range skills after the balanced reading instruction program. One possible interpretation might be because of the same stimuli were used in these three tasks. And the other possibility was because they were similarly correlated to each other.

Table 3

Results of phonological awareness pre/post test

\begin{tabular}{|c|c|c|c|}
\hline Student & Sub-test & Pre-test & Post-test \\
\hline \multirow{4}{*}{ SB1 } & Rhyming perception & 16 & 20 \\
\hline & Phoneme identity - perception & 12 & 20 \\
\hline & Rhyming production & 14 & 20 \\
\hline & Phoneme identity - production & 6 & 10 \\
\hline \multirow{4}{*}{ SB2 } & Rhyming perception & 14 & 19 \\
\hline & Phoneme identity - perception & 13 & 20 \\
\hline & Rhyming production & 14 & 18 \\
\hline & Phoneme identity - production & 7 & 10 \\
\hline \multirow{4}{*}{ SG3 } & Rhyming perception & 18 & 20 \\
\hline & Phoneme identity - perception & 16 & 19 \\
\hline & Rhyming production & 18 & 20 \\
\hline & Phoneme identity - production & 8 & 10 \\
\hline \multirow{4}{*}{ SB4 } & Rhyming perception & 10 & 16 \\
\hline & Phoneme identity - perception & 9 & 17 \\
\hline & Rhyming production & 8 & 15 \\
\hline & Phoneme identity - production & 8 & 10 \\
\hline \multirow{4}{*}{ SB5 } & Rhyming perception & 10 & 16 \\
\hline & Phoneme identity - perception & 9 & 17 \\
\hline & Rhyming production & 8 & 15 \\
\hline & Phoneme identity - production & 8 & 10 \\
\hline \multirow{4}{*}{ SG6 } & Rhyming perception & 10 & 16 \\
\hline & Phoneme identity - perception & 9 & 17 \\
\hline & Rhyming production & 8 & 15 \\
\hline & Phoneme identity - production & 8 & 10 \\
\hline \multirow{4}{*}{ SG7 } & Rhyming perception & 10 & 16 \\
\hline & Phoneme identity - perception & 9 & 17 \\
\hline & Rhyming production & 8 & 15 \\
\hline & Phoneme identity - production & 8 & 10 \\
\hline \multirow{4}{*}{ SB8 } & Rhyming perception & 5 & 14 \\
\hline & Phoneme identity - perception & 8 & 16 \\
\hline & Rhyming production & 5 & 13 \\
\hline & Phoneme identity - production & 4 & 7 \\
\hline \multirow{4}{*}{ SG9 } & Rhyming perception & 6 & 17 \\
\hline & Phoneme identity - perception & 8 & 18 \\
\hline & Rhyming production & 6 & 16 \\
\hline & Phoneme identity - production & 5 & 8 \\
\hline \multirow{4}{*}{ SG10 } & Rhyming perception & 9 & 18 \\
\hline & Phoneme identity - perception & 11 & 18 \\
\hline & Rhyming production & 10 & 17 \\
\hline & Phoneme identity - production & 6 & 7 \\
\hline \multirow{4}{*}{ SB12 } & Rhyming perception & 2 & 14 \\
\hline & Phoneme identity - perception & 4 & 15 \\
\hline & Rhyming production & 4 & 14 \\
\hline & Phoneme identity - production & 1 & 6 \\
\hline \multirow{4}{*}{ SG13 } & Rhyming perception & 3 & 14 \\
\hline & Phoneme identity - perception & 4 & 14 \\
\hline & Rhyming production & 5 & 15 \\
\hline & Phoneme identity - production & 2 & 7 \\
\hline \multirow{4}{*}{ SB14 } & Rhyming perception & 1 & 12 \\
\hline & Phoneme identity - perception & 3 & 14 \\
\hline & Rhyming production & 1 & 16 \\
\hline & Phoneme identity - production & 1 & 6 \\
\hline \multirow{4}{*}{ SB15 } & Rhyming perception & 4 & 16 \\
\hline & Phoneme identity - perception & 6 & 16 \\
\hline & Rhyming production & 5 & 16 \\
\hline & Phoneme identity - production & 3 & 16 \\
\hline
\end{tabular}




\section{Table 4}

Paired sample T-test results

\begin{tabular}{|c|c|c|c|c|c|c|c|c|c|}
\hline \multirow[t]{2}{*}{ Factors } & \multicolumn{3}{|c|}{ Pre-test } & \multicolumn{3}{|c|}{ Post-test } & \multirow[b]{2}{*}{ df } & \multirow[b]{2}{*}{$t$} & \multirow[b]{2}{*}{$p$} \\
\hline & $n$ & $\mathrm{M}$ & SD & $n$ & $\mathrm{M}$ & SD & & & \\
\hline Letter knowledge & 15 & 47.67 & 9.65 & 15 & 54.53 & 7.06 & 14 & -4.811 & 0.000 \\
\hline Rhyming perception & 14 & 8.43 & 5.21 & 14 & 16.29 & 2.37 & 13 & -9.033 & 0.000 \\
\hline Phoneme identity - perception & 14 & 8.64 & 3.65 & 14 & 17.00 & 1.92 & 13 & -15.173 & 0.000 \\
\hline Rhyming production & 14 & 8.14 & 4.57 & 14 & 16.07 & 2.06 & 13 & -9.348 & 0.001 \\
\hline Phoneme identity - production & 14 & 5.36 & 2.71 & 14 & 9.07 & 2.59 & 13 & -4.676 & 0.193 \\
\hline
\end{tabular}

\subsection{How will balanced reading instruction program affect EFL beginners' reading attitude?}

After the balanced reading instruction program is finished the results of post-test on reading attitude questionnaire was appeared impressively. Similar to what was perceived by the weaker readers themselves and the English teacher, the parents all agreed that their children made progress in the semester, especially seven of the participants (SG7, SG9, SG10, SB11, SB12, SB13, and SB15) increased their confidence in learning English. It shows that they would volunteer answer the teacher's questions even pose questions during class time.

Moreover, after participating in the program SG7, SG9, SG10, SB11, SB12, SB13, and SB15 changed their negative attitude toward learning English. They did not like English as a subject before, but after the program they admitted that English learning was fun. One student (SB10) stated "It is more interesting to learn new words with picture and colored storybooks" (Field note, July 24, 2008).

Before interviewing selected students from the actual research the practitioner compiled their profile based on the questionnaires, own assessments and The Abecedarian Reading Assessment and observation. These five (5) students were selected based on their positive progress and improvement not just in the cram school performance but also in their public school performance. They were interviewed after the end of the class. They were asked with questions regarding to children's attitude toward reading English children books. It comprises of three (3) parts: reading belief, feeling, and behavior. And then questions about balanced reading instruction were asked at the end of the interviews.

Overall, the balanced reading instruction program has affected the participants' motivation and attitude positively in several different aspects and degrees. They have become more engaged in English learning in both school and at home, increased confidence and interest in learning English, and gained great satisfaction from being able to read independently and extensively. Therefore, cram school teachers are supposed to provide more time and create more effort to develop students' reading because reading is a complex skill and lifelong learning process.

Another crucial factor which could be seen from the results above, the participants' different learning styles encouraged the researcher to be really careful dealing with the students. On the other hand, due to high turn-over rate in cram school. Most teachers are advised to keep students as possible as they can. Although, some parents decides to quit learning in this school with various reasons. The researcher attempts to create a learning environment as comfortable interesting as possible. Considering many different learning styles, the researcher set up learning corners once in a month. In this sense, learning through reading with static nature was likely to be a mismatch to their kinesthetic learning style. 


\section{Conclusion}

The findings of the study answered the initial research questions about the strategies of organizing a balanced reading instruction to improve first grade student's reading ability, and simultaneously improve their learning attitude toward English reading. After these instructions and reading programs, most of the students improved their phonemic awareness, word recognition, reading comprehension, and spelling. In addition, significant increases in the students' learning attitudes toward English reading were also noted.

The Quantitative data showed that almost all of the researcher's students had made adequate progress in their reading development. Some had actually made quite amazing progress since the beginning of the semester. It is found that the students demonstrated more confidence in reading, more fluent reading, increased sight vocabulary, improved ability to use cues and strategies, better phonemic awareness and ability to use phonics, improved comprehension and increased attitude toward reading. In addition, during independent reading students tend to ask for more books. Some general findings are as follows:

$>\quad$ Balanced reading instructions worked better for low to intermediate level readers enhancing letter knowledge and phonological awareness and reading attitude

$>\quad$ It built a positive atmosphere for stronger readers who could collaborate with the low level readers to create a healthy environment.

$>\quad$ It built up students' confidence and enhances students reading not just in school but also at home.

$>\quad$ Improve in phonic skills, reading comprehension and ability to complete simple written responses in reading journal.

Additional specific implications are as follows:

$>\quad$ More confidence during reading class and increased vocabulary spelling - the results indicated that the BRI program enhanced seven of fifteen participants' motivation to learn English (SG7, SG9, SB10, SB11, SB12, SB13 and SB15). Their confident showed during class time, when they volunteer to answer teacher's questions and sometimes even pose questions. They also believed that even if the difficulty level of learning contents in their English class would increase in the future, they had the confidence to overcome it.

$>\quad$ Improved phonics skills - Individual reading conferences books and the Abecedarian test indicated that almost all students improved their phonemic awareness and their phonics skills, as well as their ability to use these skills to decode.

$>\quad$ Improved reading comprehension and ability to complete simple written responses in reading journals - Students reading journals confirmed that the students had increased their reading comprehension, as demonstrated in their ability to respond appropriately to the books that they had read.

\subsection{Implications}

Throughout this inquiry into practice, the researcher identified some important aspects of a successful intervention program for struggling readers. The researcher clarified the understanding of the several suggestions for cram school which are essential in an instructional program that will support the reading development of all children.

First, the researcher noted that the underachievers should have an intensive program, which will ensure more time for building their reading skills ability. Through smaller group or individualized strategies and activities by more specific instruction in applying sigh vocabulary, phonemic awareness, phonic skills and more 
Balanced reading instructions: An action research on elementary cram school students

beginners reading, the underachievers will enable to increase their reading ability and motivation of learning English.

Second, the researcher discovered English teachers are supposed to provide students with varied reading materials in order to improve their English comprehension. There are several teaching strategies that are effective in supporting children. Teaching Phonics will improve the students' ability to recognize words. Beside the strategies of reading partners, guided reading, the use of word study, rewards and incentive programs, making words activities, and the use of a wide variety of leveled fiction and non-fiction reading material will balance the students' learning.

Third, as a practitioner or English teacher should use pictures and words in picture storybooks to comprehend students' reading on text. Finally, the researcher is now even more certain that children who struggle to read can be helped with well-planned, intensive, individualized intervention programs. The researcher also revealed that interaction and input of partners, professional's colleagues, and parents of the students are helpful and insightful. Although she felt that it was her responsibility to create the appropriate environment and to establish the teaching procedures necessary for the students to learn to read, it was difficult for her to do the whole task alone, especially for the weaker readers in her class. The researcher needed the assistance of colleagues to help implement the strategies that the researcher felt would lead to improvement for all her students.

NOTE: This paper is part of a longer Master's Thesis accomplished in 2009 for the Graduate Program of Education at the National ChengChi University in Taiwan.

\section{References:}

Abbott, S., Reed, E., Abbott, R. D., \& Berninger, V. (1997). Year-long, balanced reading/writing tutorial: A design experiment used for dynamic assessment. Learning Disability Quarterly, 20, 249-263. doi:10.2307/1511311<http://dx.doi.org/10.2307/1511311>

Alexander, J. E., \& Hearhington, B. S. (1988). Assessing and correcting classroom reading problems. Glenview, Ill: Scott, Foresman.

Anderson, R. C., Hiebert, E. H., Scott, J. A., \& Wilkinson, I. A. G. (1985). Becoming a nation of readers. Washington, DC: National Institute of Education.

Baltas, J., \& Shafer, S. (1996). Scholastic guide to balanced reading k-2: Making it work for you. Jefferson City, MO: Scholastic Books.

Baumann, J. F. (1996). Conflict or compatibility in classroom inquiry? One teacher's struggle to balance teaching and research. Educational Researcher, 25(7), 29-36. <http://www.jstor.org/stable/1176522>

Berk, L. E. (1996). Infants, children, and adolescents. Needham Heights, MA: Allyn \& Bacon.

Blair-Larsen, S. M., \& Williams, K. A. (1999). The balanced reading program: Helping all students achieve success. ERIC Document Reproduction Service. (ERIC Document Reproduction Service No. ED435967)

Breznitz, D. (2005). Development, flexibility, and R\&D performance in the Taiwanese IT industry - Capability creation and the effects of state-industry co-evolution. Industrial and Corporate Change, 14(1), 153-187. doi:10.1093/icc/dth047 <http://dx.doi.org/10.1093/icc/dth047>

Clay, M. M. (1994). Reading recovery: a guidebook for teachers in training. Portsmouth, NH: Heinemann.

Cohen, L., Manion, L., \& Morrison, K. (2007). Research methods in education. New York: Routledge.

Cowen, J. E. (2004). A balanced approach to beginning reading instruction: A synthesis of six major U.S. research studies. Newark: International Reading Association

Crystal, D. (1997). English as a global language. Cambridge, UK: Cambridge University Press.

Engleza, R. (2006). English as a global language. Retrieved September 12, 2008, from http://www.e-referate.ro/referate/English_as_a_global_language2006-11-06.html

Fan, S. L. (2006). Speech by vice minister of education Fan, Sun-lu. Retrieved August 1, 2008, from http://english.moe.gov.tw/ct.asp?xItem=291\&ctNode=369\&mp=11

Fishbein, M., \& Ajzen, I. (1975). Belief, attitude, intention, and behavior: An introduction to theory and research. Reading, MA: Addison-Wesley.

Foorman, B. (1996). An experiment comparing balanced grade-1 to whole language and skills emphasis 
instruction. Journal of Educational Psychology, 88, 639-652. doi:10.1037/0022-0663.88.4.639

$<$ http://dx.doi.org/10.1037/0022-0663.88.4.639>

Fu, Y. C. (2008). The effects of balanced reading instruction on elementary school students' English word recognition, reading comprehension, and reading attitude. Unpublished Masteral thesis, National Ping Tung University of Education, Ping Tung.

Gagne, R. M. (1985). The conditions of learning and theory of instruction (4th ed.). New York Holt, Rinehart and Winston.

GIO. (2007a). Mainstream education. Retrieved August 4, 2008, from http://www.gio.gov.tw/ct.asp?xItem=32865\&ctNode $=2598$

GIO. (2007b). Modernization and Chinese culture. Retrieved August 7, 2008, from http://www.gio.gov.tw/info/taiwan-story/culture/edown/3-2.htm

GIO. (2007c). Recent rankings of the investment environment of Taiwan. Retrieved August 8, 2008, from http://www.taiwanembassy.org/ct.asp?xItem $=48870 \& c t$ Node $=458 \& \mathrm{mp}=102$

Glaser, B. G. (1978). Theoretical sensitivity: Advances in the methodology of grounded theory. Mill Valley, CA: Sociology Press.

Gove, P. B. (1986). Webster's third new international dictionary. Springfield, MA: Merriam-Webster Inc.

Gunner, A. S., Smith, J. A., \& Smith, S. D. (1999). Improving comprehension and attitude toward reading using a balanced reading approach. Unpublished Masteral thesis, Saint Xavier University, Chicago, Illinois.

Hecht, A. S., Burgess, R. S., Torgesen, K. J., Wagner, K. R., \& Rashotte, A. C. (2004). Explaining social class differences in growth of reading skills from beginning kindergarten through fourth-grade: The role of phonological awareness, rate of access, and print knowledge Reading and writing. doi:10.1023/A:1008033824385 < http://dx.doi.org/10.1023/A:1008033824385>

Her, J. H. (2007). The globalization of English: Its impact on English language education in the tertiary education sector in Taiwan. Unpublished Masteral thesis, University of Waikato, Waikato.

Hill, S. (1999). Guiding literacy learners: Focus on literacy. Victoria: Eleanor Curtain Publishing.

Holdaway, D. (1979). The foundations of literacy. Sydney: Ashton Scholastic.

Honig, B. (1996). Teaching our children to read: The role of skills in a comprehension reading program. Thousand Oaks: Corwin Press.

Kelly, H. (1997). How children learn to derive meaning from text. ERIC Document Reproduction Service. (ERIC Document Reproduction Service No. ED416459)

Kolb, D. (1984). Experiential learning - Experience as the source of learning and development. Englewood Cliffs, New Jersey: Prentice-Hall.

Li, C. H. (1992). Reading in English. Zhenzhou, China: Henan University Press.

McKernan, J. (1991). Curriculum action research. London: Kogan Page.

MOE. (1997). General guidelines of grade 1-9 curriculum of elementary and junior high school education. Retrieved June 5, 2008, from www.apecneted.org/resources/downloads/Chionese_Taipei_Nine_year_Curriculum_\%20Guidelines.pdf

MOE. (2001). General guidelines of grade 1-9 curriculum of elementary and junior high school education. Retrieved July 13, 2008, from www.fhjh.tp.edu.tw/eng_www/G1-9\%20curriculum.doc

Mok, K. H. (2005). Fostering Entrepreneurship: Changing Role of Government and Higher Education Governance in Hong Kong. Research Policy 34, 537-554.

Oladejo, J. (2005). Parents' attitudes towards bilingual education policy in Taiwan. Unpublished Masteral thesis, National Kaohsiung Normal University, Kaohsiung.

Pearson. (2006). No Child Left Behind, early assessment, and pearson. Retrieved October 1, 2008, from http://ags.pearsonassessments.com/readingfirst/article.asp

Peng, M. (2008). MOE, English teaching policy sparks storm of controversy. Taiwan Journal, 25(23).

Pernai, K., Pulciani, J., \& Vahle, H. (2000). Piecing together phonics and whole language: A balanced approach. ERIC Document Reproduction Service. (ERIC Document Reproduction Service No. ERD 447446)

Pikulski, J. J. (1994). Preventing reading failure: A review of five effective programs. The Reading Teacher, 48(1), 30-39.

Pressley, M. (2006). What the future the reading research could be? Chicago, Illinois: International Reading Association Reading Research

Pressley, M., Weaver, C., \& Alterman, K. (1998). Reading instruction that works: The case for balanced teaching. New York: The Guilford Press.

Regina, S. K. (1992). English language arts: A curriculum guide for the elementary level Saskatchewan Education. <http://www.sasked.gov.sk.ca/docs/ela/index.html>

Schutz, R. (2006). English made in Brazil [Electronic Version]. Retrieved March 22, 2006, from http://frankherles.wordpress.com/2007/11/27/the-history-of-the-english-language/ 
Balanced reading instructions: An action research on elementary cram school students

Shanahan, T., \& Barr, R. (1995). Reading Recovery: An independent evaluation of the effects of an early instructional intervention for at risk learners. Reading Research Quarterly, 30, 958-996. doi:10.2307/748206 <http://dx.doi.org/10.2307/748206>

Snow, A. E., Burns, M. S., \& Griffin, P. (1998). Preventing reading difficulties in young children: National Research Council.

Strauss, A., \& Corbin, J. (1990). Basics of qualitative research: Grounded theory procedures and techniques: Sage Publications.

Strickland, D. S., \& Schickedanz, J. A. (2004). Learning about print in preschool: Working with letter, words, and beginning links with phonemic awareness. USA: International Reading Association.

Torgesen, J. K. (2000). Individual differences in response to early interventions in reading: The lingering problems of treatment resisters. Learning Disabilities Research and Practices, 15(1), 55-64. doi:10.1207/SLDRP1501_6<http://dx.doi.org/10.1207/SLDRP1501_6>

Tsai, S. (1998). The effects of cooperative learning on teaching English as a foreign language to senior high school students. Unpublished Masteral thesis, National Kaohsiung Normal University, Kaohsiung.

Tsai, T. C. (2006). Balanced reading instruction model and the experimental study on the effects of this model for EFL students in senior high school. Unpublished doctor dissertation. National Kaohsiung Normal University.

Wang, C., \& Savignon, S. (2001). Communicative language teaching in EFL contexts: Learner attitudes in Taiwan. Paper presented at the Eighteenth Conference on English Teaching and Learning in the Republic of China, Taipei, Taiwan.

Weaver, C. (1998). Toward a balanced approach to reading in reconsidering a balanced approach to reading. ERIC Document Reproduction Service. (ERIC Document Reproduction Service No. ED418388)

Wren, S., \& Watts, J. (2002). The Abecedarian reading assessment. Austin, TX.

Wren, S., \& Watts, J. (2003a). The Abecedarian reading assessment. Retrieved September 30, 2008, from http://www.balancedreading.com/assessment/abecedarian.html

Wren, S., \& Watts, J. (2003b). Reading assessment. Retrieved September 30, 2008, from http://www.balancedreading.com/assessment.html

Wu, D. C. (2003). To teach English effectively. Beijing, China: Beijing Education Press.

Zaharia, E. S., \& Gilbert, E. (2005). The entrepreneurial university in the knowledge society. Higher Education in Europe, 31(1), 31-40. doi:10.1080/03797720500088038

<http://dx.doi.org/10.1080/03797720500088038> 
Chou, C. P., Wang, S., \& Ching, G. S. 